\section{Havet, døden og ensomheten}

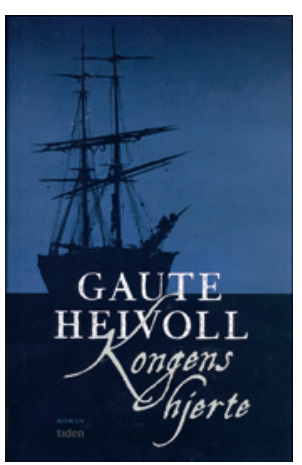

Gaute Heivoll

Kongens hjerte

229 s. Oslo: Tiden Norsk Forlag, 2011.

Pris NOK 379

ISBN 978-82-10-05161-6
Mange vil kjenne Gaute Heivoll (f. 1978) fra hans gjennombruddsroman Før jeg brenner ned (1), hvor han utforsket grenseområdene mellom fiksjon og virkelighet. Det gjør han i den foreliggende boken også. Men mens forfatteren i den første tok utgangspunkt i reelle hendelser fra hans egen barndom, er utgangspunktet for denne nye hendelser som strekker seg mer enn 200 år tilbake i tid. Og mens den første hadde en medrivende nerve som tvang leseren til å følge med, er Heivoll sparsom med ytre begivenheter i Kongens hjerte: Det meste som skjer av ytre handling, får vi på de siste 30 sidene. Det er et indre drama som preger resten.

Handlingen er lagt til året 1775, og vi følger en mann som ledsager sin syke datter, som skal fraktes med skip til København for å legges inn på Det kongelige Frederiks Hospital. Datteren har radesyke, og sammen med de to er det 12 andre pasienter med samme sykdom, i tillegg til legen, chirurgus Hendrich Deegen (ca. 1740-92). Pasientene er stuet sammen i et rom i skipets indre. Stemningen der nede er trykkende, ingen søker hverandres selskap, alle er iltre og mistenksomme. Det er en navnløs flokk - de eneste som har navn, er Deegen og den døde søsteren Siri, som i likhet med moren døde av radesyke før handlingen tar til.

\section{Stinkende sår}

Heivoll bruker et språk som gjør tilværelsen nede i skipet levende: Vi lukter de stinkende sårene, blir kvalme over fortellinger som maler frem den gulgrønne materien, får vondt av beskrivelsen av bandasjer som må rives av. Vi får en rekke nærgående beskrivelser av illeluktende byller, smertefulle behandlinger (kvikksølvsalve), kirurgisk fjerning av nekrotiske sår og av gryende galskap. Som her, av en mann som døde på skipet: «Sårene gapte mot dem. Man kunne se ribbeina grågule som hestetenner innhyllet i kaker av svart kjøtt og bleke hudfolder. Stanken ble ført bort med vinden.» Flere dør på overfarten. Disse fysiske og materielle beskrivelsene er nærværende i teksten, kanskje først og fremst når det handler om sykdom og utslett.

Men er romanen historisk? På en måte er den det. Det er noe genuint fremmed, annerledes, over beskrivelsen av en sau med redde øyne i møte med faren som blir sendt på land for å skaffe mat. Det er langt fra danskebåten til trosser som må hives og seil som rives, fra trafikklysene i dagens København til de dunkle og mystiske tranbelyste gatene i København. Om radesyken lærer vi strengt tatt ikke så mye. Men gjør det noe?

\section{Historisk roman?}

Jeg er bedt om å anmelde boken fordi radesyken var emnet for min avhandling (2). Det er selvfølgelig fristende å påpeke at reisen foregikk i 1776, ikke i 1775, som det står både i Heivolls korte introduksjon og i baksideteksten. Det var det danske kanselli som hadde foreslått for Collegium Medicum om ikke noen «til prøve» skulle sendes ned til København for at man slik skulle få vite mer om sykdommen, som ennå var en gåte for de medisinske autoritetene.

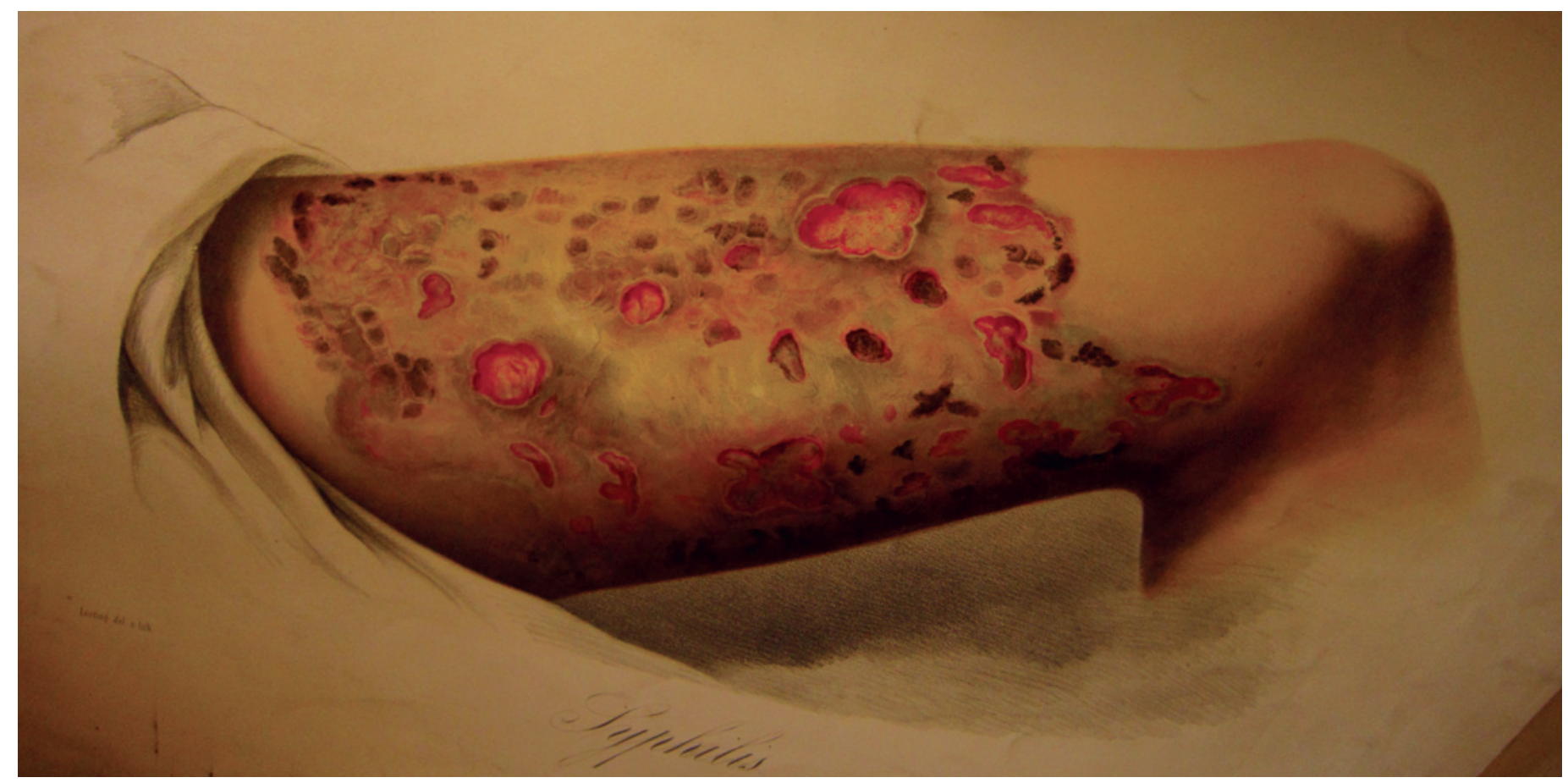

Et bein med radesyke, tegnet 80 år etter at pasientene Heivoll skriver om, ble sendt til København. På denne tiden ble radesyken forstått som en avart av syfilis. Tegningen er ved JL Losting. Foto Øivind Larsen 


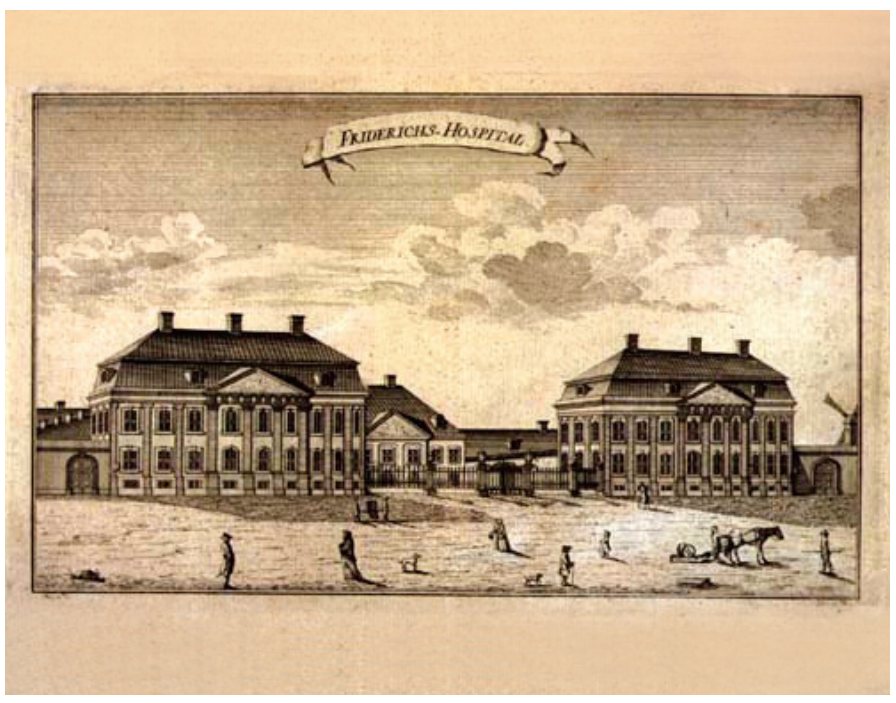

Det kongelige Frederiks Hospital i København, som var målet for reisen pasientene med radesyke la ut på 10. april 1776. Sykehuset ble bygd i 1752 og var det første sykehuset i Danmark-Norge som hadde behandling som hovedformål. Foto Wikipedia

Formålet med reisen skulle være todelt: Man skulle bli kjent med sykdommens egentlige natur, dvs. få vite hva sykdommen var, og man skulle få gode måter å behandle den på, som igjen kunne brukes på de mange som lå syke med sykdommen i Norge. Reisen ble utsatt til våren, fordi det var så barskt klima om høsten og vinteren. Det ingen hadde regnet med, var at det ville bli så vanskelig å få tak i pasienter. Særlig slet Deegen med å skaffe pasienter, og han klaget til stiftsamtmannen om at bare bøndene hørte det minste nyss om reisen til København, så flyktet de, og reiste heller til kvakksalvere i Arendal eller Kristiansand for å la seg behandle. Det var en viss uenighet om hva motstanden mot å bli med skyldtes. Deegen mente at det skyldtes at pasientene hadde større tiltro til kvakksalvere enn til de lærde i København, mens fogden mente at pasientene flyktet fra Flekkefjord fordi de ikke hadde noen tiltro til Deegen. Men ingen var i tvil om at kongens ordre skulle oppfylles, og løsningen ble derfor å la lensmennene hente pasienter som Deegen foreslo. For det første skulle seks pasienter hentes fra Stavanger, slik at Deegen bare måtte samle seks, og for det andre skulle lensmennene hjelpe Deegen å søke ut de som skulle bli med. Makt kunne brukes hvis det var nødvendig, bekreftet stiftsamtmannen. Skipet la fra land i Flekkefjord 10. april 1776, med Deegen og hans seks pasienter og doktor Tychsen fra Stavanger og hans sju pasienter. Pasientene var i alderen 9-50 år, de fleste mellom 20 og 40. Fire pasienter døde i sykehuset samme år, like mange ble skrevet ut i juli og august (2).

Det er unektelig noe underlig at Heivoll har unnlatt å bruke rammefortellingen om tvangsbruk. Her kunne det ha vært mulighet for en dramatisk nerve i en fortelling som kanskje lider noe under mangel på fremdrift. En mulighet som ikke hadde vært å gjøre vold på det historiske materialet, kanskje snarere tvert om. Visste han ikke om det eller ønsket han ikke å bruke det? Svaret er for så vidt

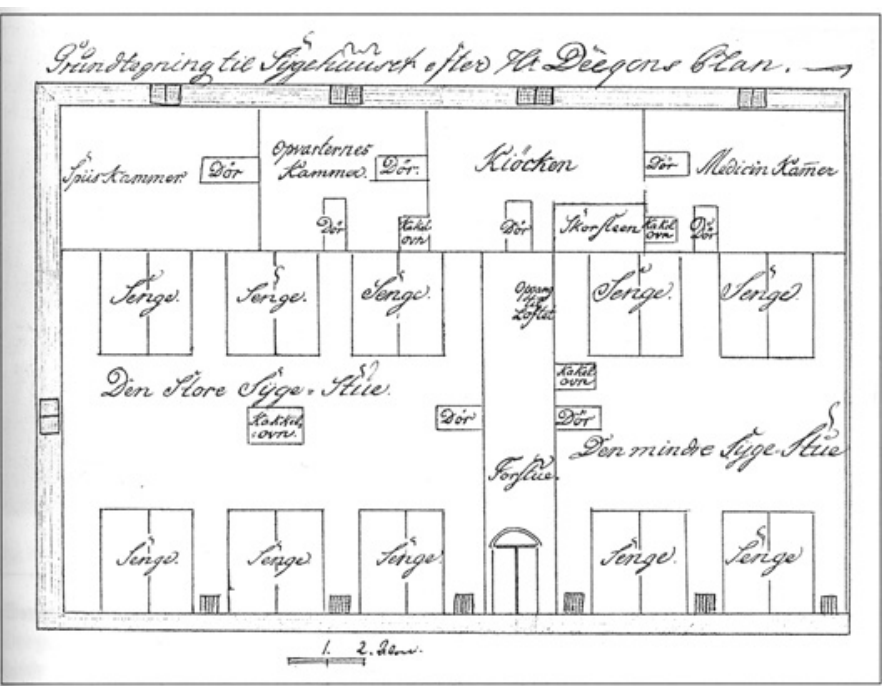

Hendrich Deegen sto selv for disse tegningene til radesykehuset i Flekkefjord. Sykehuset ble innviet høsten 176, da Deegen kom hjem etter å ha vært i København. At legen laget sykehustegningen er et av mange uttrykk for at sykehusene på denne tiden blir medisinske arenaer. Foto Statsarkivet i Kristiansand

irrelevant. Det ville neppe blitt en bedre bok om han hadde gjort det, og det hadde muligens tatt søkelyset vekk fra det som er hovedanliggende, forholdet mellom far og datter.

\section{Eksistensiell ensomhet}

Mange anmeldere har påpekt at dette først og fremst er en roman om et skjørt kjærlighetsforhold mellom far og datter. Gaute Heivoll har et stykke på vei bekreftet dette gjennom å dedikere boken til sin datter, som ble født mens han var i ferd med å avslutte romanen.

Jeg leser den annerledes. For meg er dette i første rekke en roman om vanskeligheten ved å ha fellesskap, selv til de aller nærmeste, når man er så syk og svak at man ikke engang orker å snakke. Hvordan kan man dele av seg selv når man har mer enn nok med å håndtere at tennene faller ut og kroppen sakte råtner bort? Og hvordan skal en far greie å skjerme datteren for sin egen smerte ved synet av henne når hun visner hen? Dette er aktuelle spørsmål som ikke først og fremst handler om radesyken. Da blir det irrelevant at årstallet ikke er korrekt, at Deegen kanskje ikke behandlet pasientene sine med kvikksølv på den måten Heivoll beskriver, eller at det neppe døde tre mennesker på overfarten med skipet.

Dette er rett og slett ikke primært en historisk roman, det handler om ensomhet - og kjærlighet - ved alvorlig sykdom og død.

\section{Anne Kveim Lie}

Tidsskriftet

\section{Litteratur}

1. Heivoll G. Før jeg brenner ned. Oslo: Tiden, 2010

2. Lie AK. Radesykens tilblivelse. Historien om en sykdom. Doktoravhandling Oslo: Universitetet i Oslo, 2008. 